\section{Canadian AIDS suit raises hopes for HIV-blood victims}

Montreal. A flood of lawsuits is expected to follow the decision to award more than half a million Canadian dollars to the HIVinfected wife of a man who died of AIDS after receiving a transfusion of HIVcontaminated blood. Kenneth Arenson, the lawyer for Rochelle Pittman, said last week that he has 19 other clients who intend to pursue legal action against the Canadian Red Cross Society, individual hospitals and the province of Ontario.

The outcome of the Pittman case was announced on the eve of a deadline set by all except one of Canada's provinces and territories for acceptance of a compensation package by more than a thousand recipients of HIV-infected blood. To obtain the money, victims had to sign waivers promising not to sue Ottawa, the provinces or territories, hospitals, the Red Cross and pharmaceutical and insurance companies.

But many consider the package inadequate, as it offers far less than the C $\$ 515,000$ (US\$380,000), plus interest and legal fees, that Pittman - who was ineligible for the package because she was infected sexually through her husband, and not directly - is likely to receive.

The package also less generous than the province of Nova Scotia, which, as well as making annual payments of $C \$ 30,000$ to victims, pays for expensive AIDS drugs, as well as funeral costs and post-secondary education for their children.

The Ontario Court ruled in Pittman's case that the Red Cross, the Toronto Hospital and her general practitioner were negligent in failing to tell her husband that he had been infected by contaminated blood. His wife discovered later that she had become HIV-positive.

But the court ruled that the Red Cross had not been negligent in its efforts to safeguard blood supplies before 1985, when national screening for HIV started. This will complicate the legal claims of other haemophiliacs and transfusion patients.

Pittman's was one of many stories presented to a commission of inquiry into Canada's blood supply system, set up last October. The commission is holding nationwide hearings on the working of the system, including the events surrounding contamination of blood supplies in the early 1980 s. Its report is expected to be completed by the end of September.

More than two million Canadians received transfusions between 1978 and 1985 , and epidemiologists believe that, in addition to the thousand or so individuals known to have been infected in this way, a further 200 may also have been infected.

David Spurgeon

\title{
French fast reactor proposal still breeds controversy
}

Paris. Last month's decision by the French government to restart the Superphénix fastbreeder reactor at Creys-Malville near Lyons, but to shift its main purpose from generating electricity to research into incinerating plutonium,

has done little to dampen the controversy that continues to surround the plant.

Superphénix, a 1,200-MW prototype reactor, was closed in 1987 following repeated leaks in the liquidsodium cooling circuits. It was to be the first of a new generation of fast breeders, designed to breed plutonium from stocks produced by France's reprocessing plant at la Hague.

The strategy anticipated that a spread of conventional reactors would lead to a shortage of uranium and make plutonium the fuel of choice. But this has not happened, and uranium remains plentiful. Moreover, such logic has been eclipsed by growing concern over the safety of storing and transporting more than 1,000 tonnes of plutonium stockpiled around the world.

Under the new plan, NERSA - a consortium of French, German and Italian utilities that owns the reactor - and the French Atomic Energy Commission (CEA) will commence a research programme aimed at converting Superphénix into a prototype for a purpose-built plutonium furnace.

The programme would be based on the CAPRA programme (Consommation Accrue de Plutonium dans les Rapides), which CEA began last autumn (see Nature 365, $381 ; 1993)$. This proposes equipping Superphénix with cores lacking a uranium blanket in 1995 and 1999 - converting a fast neutron reactor from a breeder to a consumer - and trying to raise by a factor of three the estimated maximum rate of plutonium consumption.

The reactor may be started up at low power as soon as this summer, once the proposed programme has been reviewed by Robert Dautray, the head of CEA, and Claude Detraz, director of the Institute of Nuclear and Particle Physics at the Centre National de la Recherche Scientifique (CNRS).

But many are still sceptical of the wisdom of restarting the reactor. The decision is widely seen as a political solution to the problem of satisfying the utilities companies, who have paid FFr27.7 billion to build and more than FFr600 million annually to run a reactor that has operated for a total of less than six months.
In particular, many feel that as Superphénix was not designed as a research reactor, it can only be an extremely expensive research tool poorly adapted to the job. Georges Vendryes, a former director of CEA "and 'father' of the reactor, has admitted that "we can't say that this is the ideal reactor for this sort of work".

Others doubt the technical feasibility of incinerating plutonium. Britain rejected the idea in the late 1970 s on safety and economic grounds. One senior scientist who worked on the European fast reactor programme says that incineration would be incomplete, and would leave unacceptably high levels of plutonium and minor actinides.

He adds that the utility companies will not pay for the new fast breeders and extra processing that large-scale incineration would require. "It's not a solution," he says.

Despite such criticisms, Electricité de France (EDF) has welcomed the proposal, and says it hopes that research using Superphénix will lead to France building one plutonium-furnace for every five waterpressurized reactors.

Furthermore, Gerhart Heusener, who heads nuclear safety at the Karlsruhe Nuclear Research Centre in Germany and leads German participation in CAPRA, has also argued that the major stumbling block to incineration is simply lack of research. "Perhaps incineration is no use," he says. "But CAPRA will at least let us find out."

EDF's partners in NERSA say that any option would be better than closing Superphénix - which would have cost around FFr 18 billion on top of their original investments. But they are waiting until they have a meeting with the French government before taking a formal position.

Alexandre Autieri, the deputy permanent secretary of NERSA, says that "we will try to use Superphénix as a research reactor, but our major interest is to produce electricity". He points out that a fast-breeder produces as much electricity when it consumes plutonium as it does when it breeds it, and says "the new orientation is possibly not opposed to our original aim".

Indeed, although one result of the switch in the goals of Superphénix is that EDF will no longer be able to dictate power levels, the output of the reactor may be progressively increased up to much the same level as that originally intended.

Declan Butler 